Área Abierta. Revista de comunicación

audiovisual y publicitaria

ISSN: 1578-8393

http://dx.doi.org/10.5209/ARAB.54951

\title{
Ficción publicitaria radiofónica y humor: un análisis pragmalingüístico
}

\author{
María Isabel Hernández Toribio ${ }^{1}$ \\ Recibido: 13 de enero de 2017 / Aceptado: 3 de febrero de 2017
}

Resumen. La ficción constituye uno de los exponentes de la creatividad en la publicidad radiofónica. Específicamente, esta modalidad publicitaria parece haber encontrado en el humor una fórmula para llamar y captar la atención del oyente con la finalidad de conseguir la adhesión emocional que lo induzca a la adquisición del producto. Por ello, el objetivo de este trabajo es revisar las estrategias que se emplean para desencadenar los efectos humorísticos incidiendo de forma especial en las particularidades que impone la radio como soporte publicitario. Un análisis que vamos a llevar a cabo a partir de los presupuestos de la Teoría General del Humor Verbal (TGHV) (Attardo y Raskin, 1991). Además, como la publicidad constituye un discurso multimodal (Kress, 2010, Yus Ramos, 2016: 299-320) en el que convergen diversos códigos, revisaremos tanto los indicadores lingüísticos como aquellos otros recursos -música, paralenguaje y efectos sonoros- que permiten desencadenar el efecto humorístico.

Palabras clave: ficción, humor, radio, publicidad, pragmática

\section{[en] Fiction in Radio Advertising and Humor: A Pragmalinguistic Analysis}

\begin{abstract}
Fiction is an essential component of creativity in radio advertising. Specifically, this type of advertising has discovered that humor is a creative formula that can be used to capture the listeners' attention and create an emotional bond that leads them to purchase the product. Thus, the purpose of this study is to review the strategies that are used to trigger a humorous response, with a special focus on the peculiarities of radio as an advertising medium. This analysis will be carried out using the General Theory of Verbal Humour (GTVH) (Attardo and Raskin, 1991). In addition, since advertising is a multimodal discourse (Kress, 2010, Yus Ramos, 2016: 299-320) in which a variety of codes converge, we will examine both the linguistic indicators of humor and those from other audio resources - music, paralanguage, and sound effects - that trigger a humorous response. Keywords: Fiction, Humor, Radio, Advertising, Pragmatics
\end{abstract}

Sumario. 1. Introducción. 2. Marco teórico. 3. Metodología y corpus de análisis. 4. Análisis y resultados. 5. Conclusiones. 6. Bibliografía.

Cómo citar: Hernández Toribio, M. I. (2017) Ficción publicitaria radiofónica y humor: un análisis pragmalingüístico, en Área Abierta. Revista de comunicación audiovisual y publicitaria 17 (1), 99-116. http://dx.doi.org/10.5209/ARAB.54951

1 Universidad Complutense de Madrid (España)

E-mail: ihtor@ccinf.ucm.es 
Dedicado a Ana María Vigara, gran especialista en el análisis del humor.

\section{Introducción}

La publicidad radiofónica parece haber encontrado en la ficción una fórmula idónea para captar y llamar la atención de un destinatario escasamente motivado ante el descrédito generalizado hacia esta modalidad publicitaria. El potencial creativo que se atribuye a otras modalidades audiovisuales tradicionales o la posibilidad de interacción que ofrecen las nuevas fórmulas de la publicidad online condicionan y coartan las posibilidades creativas de la radio, al menos de su formato tradicional: la cuña. Pero, a pesar de ello, se realizan esfuerzos por relanzar una creatividad articulada en torno a la palabra, la música y otros efectos sonoros - rasgos paralingüísticos, ruidos-, y se cuenta con la ficción radiofónica como el instrumento para recuperar las posibilidades expresivas de la radio (Rodero Antón y Xoengas Pérez, 2010; Arcos Foix y Perona Páez, 2011, Muela Molina, 2012).

La publicidad, a su vez, ha encontrado específicamente en las manifestaciones humorísticas una fórmula que, aunque no sea mayoritaria, resulta idónea para recrear la ficción radiofónica. El humor es una de las estrategias a las que se recurre para llamar y captar la atención del destinatario y, en este sentido, puede constituir uno de los recursos «atencionales» propios de la publicidad - junto con otros como las repeticiones- (Rodero Antón, 2014). Duncan y Nelson (1985: 35) constataron en un estudio sobre los efectos del humor en la publicidad de radio que este parece incrementar la atención del oyente, el gusto por el anuncio y por el producto. Es más, el humor, en general, constituye una estrategia mediante la que se busca la complicidad del oyente y su adhesión emocional, porque los enunciados y situaciones que desencadenan efectos humorísticos crean en los interlocutores «impresiones comunes y sensación de complicidad mutua» (Torres Sánchez, 1999: 103), estrechar los lazos entre hablante y oyente al requerir de estos una colaboración (Alvarado, 2016: 195). Refuerza la solidaridad del grupo y las relaciones entre sus miembros (Yus Ramos, 2016: 37). El humor está ligado al «placer compartido» (López Díaz, 2008: 26); activa la participación del receptor, lo invita a que reaccione en la creación final del discurso y active el recuerdo (Catalá Pérez, 2010). La audiencia siempre parece más receptiva hacia los mensajes festivos que hacia los serios (León, 2001: 14). La publicidad explota, además, el tipo de humor que busca la «connivencia lúdica», la fusión emocional (Charaudeau, 2006), es decir, una complicidad basada en el mero efecto lúdico, desprovista de toda crítica de valores, aunque esta pueda estar latente.

Si, el humor resulta eficaz en la publicidad (López Díaz, 2008; Catalá Pérez, 2010; Hernández Toribio y Vigara Tauste, 2011), en general, cada modalidad, en función de sus peculiaridades, hace un uso especial. Por ello, el objetivo general de este trabajo se centra en analizar el humor en la publicidad de radio en función de los condicionantes del medio: su carácter oral-auditivo, la fugacidad y simultaneidad de la escucha con la realización de otro tipo de actividades, la ausencia de imágenes visuales o su carácter próximo como prolongación de la cotidianeidad del oyente. Por una parte, revisaremos las estrategias mediante las que se intenta que el humor encaje con las particularidades que la radio presenta como soporte publicitario. Mostraremos las estrategias y los procedimientos humorísticos recurrentes en el 
formato cuña a partir de la Teoría General del Humor Verbal (TGHV) (Attardo y Raskin, 1991). Por otra, puesto que la publicidad constituye un discurso multimodal en el que convergen diversos códigos o presuntos códigos, comprobaremos cómo tanto los recursos lingüísticos - pues el poder de la palabra resulta innegable en este medio-como paralingüísticos - las cualidades de las voces empleadas-, la música y los efectos sonoros resultan claves en ausencia de la imagen visual -de extraordinaria eficacia en otras modalidades audiovisuales- para conseguir el efecto humorístico.

\section{Marco teórico}

Si el análisis del humor en la publicidad, realizado desde diferentes ámbitos de investigación -marketing, psicología, sociología, antropología, lingüística, etcétera- ha dado lugar a una extensa bibliografía, poco se ha dicho al respecto sobre los mecanismos empleados en la publicidad radiofónica y menos aún desde una perspectiva lingüística. Si nos centramos en los estudios sobre el humor en la publicidad en español, constatamos la existencia de algunas aproximaciones realizadas desde la perspectiva pragmática en la que enmarcamos este trabajo (entre otros, Blanco Rodríguez, 2006; López Díaz, 2008; Catalá Pérez, 2010, 2011; García Vizcaíno, 2010, 2016; Hernández Flores, 2010; Rodríguez Rosique y Provencio Garrigós, 2012), pero que centran su análisis en corpus de publicidad gráfica o audiovisual; y más recientemente en Twitter (Pano Alamán y Mancera Rueda, 2016: 35-56).

Partimos de los presupuestos de la Teoría General del Humor Verbal planteada por Attardo y Raskin (1991) así como de la adaptación realizada por Ruiz Gurillo (2012), su posterior revisión y las nuevas aportaciones planteadas por la autora (Ruiz Gurillo, 2016). En concreto, para el análisis de los ejemplos que nos permitirán ilustrar las tendencias generales registradas en la publicidad radiofónica, tendremos en cuenta las fuentes de conocimiento que permiten interpretar un texto como humorístico: la oposición de guiones que resultan incongruentes; los mecanismos lógicos que permiten conectarlos; la situación o el contexto que rodea el discurso; la meta o el blanco del humor; las estrategias narrativas (chiste, acertijo, historia...) empleadas y los recursos lingüísticos que actúan como indicadores humorísticos.

Si bien el análisis de los ejemplos propuestos nos permitirá revisar todas estas fuentes de reconocimiento, haremos especial hincapié en cómo las particularidades del soporte publicitario, en correlación con las características de este discurso, determinan la selección de los recursos y la interpretación del texto como humorístico. Recientemente, Ruiz Gurillo (2016: 79-101) y Alvarado Ortega (2016: 193-214) han propuesto un modelo a partir del que explican el humor como una elección continua partiendo de las nociones pragmáticas - planteadas por Verschueren (2002)- de variabilidad, negociabilidad y adaptabilidad.

\section{Naturaleza del objeto de estudio}

Para llevar a cabo nuestro estudio hemos configurado el corpus Radioling (recopilado en los anuncios recogidos en el archivo de la revista online de publicidad y marketing 
Anuncios.com). Este corpus está compuesto por cien cuñas humorísticas emitidas en las principales emisoras de radio en España durante todo el año 2016. El corpus se ha sistematizado en función de las modalidades ficcionales en la publicidad de radio propuestas por Guarinos (1991) y Arcos Foix y Perona Páez (2011): ficción dramatizada, narrada e ilustrativa o testimonial mediática.

Para revisar cómo se intenta generar el humor en las cuñas de ficción radiofónica articulamos el trabajo en torno a dos aspectos que nos permiten ilustrar cómo se apoya de forma recurrente en algunas estrategias:

a) La trivialización de situaciones cotidianas - mediante diálogos, testimonios de personajes o historias contadas por un narrador- fácilmente identificables a priori por el oyente en tanto que prolongación de su cotidianeidad.

b) La intertextualidad o referencia a textos previos. Incluimos en este apartado también la retroalimentación de campañas audiovisuales -mayoritariamente televisivas- previas o simultáneas a la emisión de la cuña.

En segundo lugar, esbozaremos las estrategias lingüísticas más frecuentes en este formato publicitario y los recursos no lingüísticos propios de este discurso multimodal que actúan como marcas de humor.

\section{Análisis y resultados}

\subsection{La radio como soporte publicitario y el humor}

La radio se caracteriza por ser un medio oral-auditivo y, en consecuencia, fugaz, en el que los mensajes se suceden vertiginosamente, por lo que si bien las estrategias creativas que buscan los efectos humorísticos encajan perfectamente con la necesidad de captar y llamar la atención de un destinatario que habitualmente no realiza una escucha activa, sino que simultanea esta con la realización de otro tipo de actividades, esta circunstancia se convierte también en un condicionante importante que limita las posibilidades expresivas del humor. Este se ve coartado por las características de un medio que se articula en torno a la palabra y que, sin menospreciar la relevancia de otros recursos sonoros de diversa naturaleza, adquiere un protagonismo especial. Como usuarios, parece que hemos establecido una perfecta simbiosis entre las imágenes visuales y la publicidad en detrimento de aquellas modalidades que, como la radio, no disponen de ellas y han de manejar esencialmente la palabra.

A los condicionantes que imponen las características del medio hay que sumarle las particularidades del humor, que juega con la ruptura de expectativas y, consecuentemente, supone para el destinatario un mayor esfuerzo de procesamiento cognitivo puesto que la interpretación del sentido último del mensaje requiere de un proceso inferencial. Según la Teoría de la incongruencia (Torres, 1999; Attardo, 2001; Catalá Pérez, 2010; Ruiz Gurillo, 2012), el humor se basa en una realidad o pensamiento incongruente con lo que se esperaba. De ahí que obtener el sentido último del mensaje supone conectar dos guiones opuestos que resultan incongruentes (Attardo y Raskin, 1991, Ruiz Gurillo, 2012) por lo que el esfuerzo de procesamiento cognitivo que el interlocutor tiene que realizar es superior. Y, aunque el incremento de dicho esfuerzo se vea recompensado por el efecto humorístico que este proceso 
puede producir en el sujeto, el mensaje ha de resultar, en última instancia, eficaz y efectivo. En términos de Beaugrande y Dressler (1997), entendemos eficacia y efectividad como aquellas características textuales que determinan que el texto cause en el destinatario el mayor impacto, pero que este obtenga los mejores resultados comunicativos posibles invirtiendo en esa tarea un esfuerzo mínimo. Como pone de manifiesto Yus Ramos (2006) en su estudio sobre el humor a partir de la Teoría de la Relevancia propuesta por Sperber y Wilson, nuestro sistema inferencial está orientado a la maximización de los efectos cognitivos.

Por todo ello, el humor, como toda retórica en la ficción publicitaria radiofónica, ha de ser fácilmente inferido por el receptor como parte integrante de su imaginario popular. Como consecuencia, se recurre a una serie de estrategias como la trivialización de situaciones cotidianas fácilmente reconocibles por el oyente.

\subsubsection{Humor y trivialización de situaciones cotidianas}

La radio aprovecha el entorno afectivo próximo que establece con su audiencia. De ahí que la mímesis de situaciones cotidianas -fundamentalmente trivializadas o distorsionadas desde la óptica del humor- se ponga al servicio de la publicidad persuasiva, en sintonía con un medio que «envuelve, contacta boca a oído, persona a persona y que inspira confianza porque elimina el escepticismo provocado por la distancia y el tiempo» (Muñoz y Gil, 1994: 19). Se explota, en principio, lo aparentemente cotidiano como un buen reclamo para captar la atención del oyente. La radio no solo forma parte del entorno cotidiano, sino que penetra en los hogares $\mathrm{y}$ en los espacios personales prolongando el ambiente familiar de los oyentes y simulando establecer con estos un tipo de comunicación con gran carga afectiva. La pretendida cercanía psicológica del medio al receptor justifica este hecho (Hernández Toribio, 2006: 543-551). De ahí la constante reproducción en publicidad de todo tipo de interacciones cotidianas -que se presentan bajo diferentes formatos de ficcióncuyo referente es fácilmente identificable por el oyente, y que posteriormente serán distorsionadas para generar el humor.

a) Ficción dramatizada

Un $67 \%$ de las cuñas se presenta bajo la forma de microdramatizaciones (Guarinos, 1999: 54) o «ficción dramatizada», dialógica o no (Arcos Foix y Perona Páez, 2011: 5-6), es decir, en ellas se reproducen situaciones que desarrollan personajes a través conversaciones: entre una pareja o amigos, una transacción comercial, una boda, un juicio, una entrevista de trabajo. Entre estas, lo más habitual es que se reproduzca el prototipo discursivo de lo oral coloquial: la conversación cotidiana que mantienen personajes entre los que existe proximidad (amigos, familiares), que va a servir de acicate para el desarrollo de la información sobre el producto, expuesta posteriormente en la voz en off. Por tanto, la tendencia mayoritaria es que se reproduzca un diálogo que se desarrolla en escenarios y situaciones perfectamente identificables para el oyente en sintonía con las características de un medio como la radio que prolonga su cotidianeidad. Este tipo de cuñas representa el $43 \%$ del total y el $62,68 \%$ de aquellas clasificadas en la modalidad de ficción dramatizada, lo que da cuenta de la importancia que adquiere esta estrategia.

En estos casos, al servicio de las características que comúnmente se señalan como propias de la conversación que se intenta reproducir -expresividad, espontaneidad, 
cotidianeidad, informalidad- es recurrente seleccionar determinados recursos lingüísticos: marcadores del discurso, repeticiones, voces propias del registro coloquial, procedimientos de intensificación (Hernández Toribio, 2016).

(1) La Primitiva. Título: «Casa en la playa» (octubre 2016)

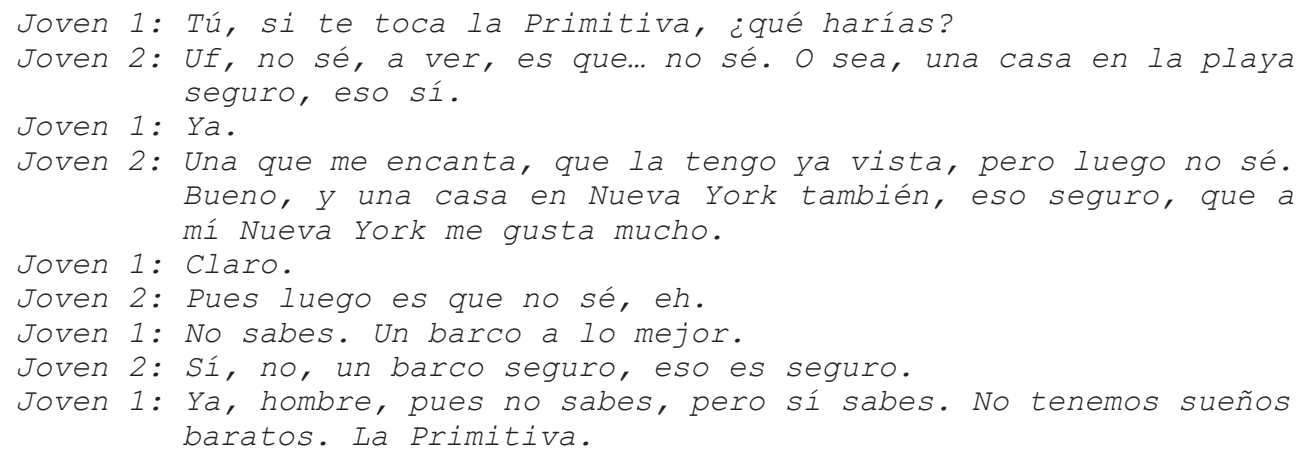

(2) Ikea. Título: «Catálogo» (octubre 2016)

Hombre: ¿Te las estás leyendo?

Mujer: Sí, sí, sí, voy por donde está la mujer haciendo un wok y, de repente, a su lado aparece una mano con un cuchillo.

Hombre: iAh!, empezaste ya el capítulo de las cocinas.

Mujer: Sí, donde los niños están...

Hombre: Calla, calla, calla, no me cuentes más, no me cuentes más, que todavía no he llegado ahí.

LOC. OFF: Llega uno de los libros más leídos del mundo. Llega el catálogo de Ikea. Ya en tu buzón o descárgatelo en tu móvil.

En el ejemplo (1) destacamos el papel de las repeticiones: la geminación «sí, sí, sí» permite reforzar la afirmación mediante la que se manifiesta aprobación; «calla, calla, calla» y «no me cuentes más, no me cuentes más» son repeticiones que intensifican la fuerza ilocutiva de los correspondientes actos directivos peticiones; «no sé, es que no sé» adquiere un papel retardatario mientras el personaje planifica lo que va a argumentar posteriormente; la construcción-eco «un barco seguro» muestra aprobación.

En (2), destacamos los marcadores del discurso propios del registro coloquial que aparecen en las intervenciones de los personajes del diálogo: «bueno» introduce un nuevo argumento — «bueno, y una casa»— como continuidad de lo anteriormente expuesto; «pues» es introductor de una respuesta — «pues luego es que no sé»en la que se manifiesta duda, valor que permite mostrar el propio marcador, que puede tener un papel retardatario mientras el hablante planifica lo que va a decir a continuación; mediante «hombre, pues» se muestra cierto desacuerdo y lo contrario mediante «jah!, claro».

Por otra parte, como también puede comprobarse a través de estos ejemplos, es muy frecuente que en la cuña se simulen todo tipo de situaciones en las que un hablante solicita información de otro, bien sobre el producto o sobre otro aspecto que, en última instancia, permita recrear un contexto que directa o indirectamente 
tenga relación con aquel. Por ello, en estos diálogos de ficción se suceden intervenciones iniciativas, reactivas o reactivo-iniciativas ${ }^{2}$. Por ejemplo, en (1) y (2), un personaje realiza en la intervención iniciativa una petición de información a través de un enunciado interrogativo que es una pregunta real: «¿qué harías?», «¿te la estás leyendo?». De hecho, se pretende imitar el contexto pragmático en el que un interlocutor aparenta tener un desconocimiento real de una información y la pretensión de obtener del destinatario una respuesta verbal a la incógnita planteada en dicho enunciado (Escandell Vidal, 1999: 3973). Y se van sucediendo intercambios, es decir, pares adyacentes de intervenciones iniciativas y reactivas (respuestas cooperativas, evaluadoras o fáticas ${ }^{3}$ ) sucesivas en las que se empieza a distorsionar la que, en principio, podría resultar una situación cotidiana fácilmente reconocible por los oyentes: una conversación entre amigos. Se van alternando intervenciones iniciativas y reactivas inesperadas, irónicas o elocuentes que consiguen el efecto trivializador y humorístico.

Así, en (1), las palabras de la intervención reactiva «Uf, no sé, a ver, es que... no sé» (respuesta cooperativa más o menos predecible a partir de una intervención iniciativa «petición de información» en las conversaciones o entrevistas reales) hacen generar en el oyente la expectativa de que es verdadera la duda que manifiesta este personaje del diálogo con el que podría identificarse cualquier oyente. Pero, de forma inmediata, podemos darnos cuenta de que no son ciertas sus palabras, pues parece tener claro qué haría verdaderamente si le tocara la lotería: tener caprichos muy caros (propios del que se presupone como estereotipo de un millonario), como, de hecho, se llega a poner de manifiesto en el propio eslogan de la cuña -«no tenemos sueños baratos»- La ironía de las palabras del personaje («no sé») de la ficción dramatizada (que detecta el segundo personaje: «hombre, pues no sabes, pero sí sabes») produce, por tanto, una ruptura de expectativas que sorprende al oyente de la cuña y puede provocar su reacción humorística (risa o sonrisa). Es más, el efecto humorístico se potencia por la acumulación (Gallud Jardiel, 2016: 141-142) y selección de determinados elementos: comprar una casa en la playa y otra en Nueva York, adquirir un barco.

En (2), el diálogo reproducido nos induce a pensar que la pareja de la ficción dramatizada dialógica está hablando de una novela negra o policíaca, pero la voz en off explicita que se trata de un catálogo de muebles muy conocido, al que califica como el libro más vendido del mundo. Se produce, por tanto, una ruptura de las expectativas que se había generado el oyente sobre el diálogo entre los protagonistas. El mecanismo lógico que permite resolver la incongruencia es un razonamiento correcto que se apoya en las dos acepciones del término libro. Se oponen dos guiones: el que lleva a interpretarlo como una obra literaria y aquel otro que considera también libro un catálogo publicitario haciendo un uso extensivo del término como «conjunto de muchas hojas de papel u otro material semejante que, encadenadas, forman un

2 Intervenciones iniciativas son aquellas que provocan una reacción posterior. Las reactivas son las reacciones a una intervención previa y las reactivo-iniciativas suponen una reacción previa y provocan una reacción posterior (Grupo Val.Es.Co, 2014: 19).

3 Las respuestas cooperativas son aquellas «predecibles a partir de las intervenciones iniciativas directas»; las respuestas evaluadoras «responden a las valoraciones de lo dicho por otro»; las respuestas fáticas «confirman los papeles comunicativos con reacciones como 'ya, ya, mm, mm' o que manifiestan interés por lo que dice el interlocutor (a menudo con carácter agradador)» (Grupo Val.Es.Co, 2014: 21). 
volumen» ${ }^{4}$. Es más, el catálogo promocional se llega a considerar como «uno de los libros más vendidos del mundo», es decir, un best seller. Ahora, los dos guiones opuestos se apoyan en un razonamiento que lleva al oyente a establecer conclusiones desde premisas falsas, basado en una hipérbole que, junto al juego con las dos acepciones de libro, contribuye también a desencadenar el efecto humorístico.

Además de las conversaciones entre familiares y amigos, se reproducen otros tipos de interacciones dialógicas: un juicio (3), una boda (4), una entrevista de trabajo (5), y una transacción comercial (6):

(3) VOLVO. Título: «Reo» (noviembre 2016)

Juez: Culpable (ruido martillo). ¿Quiere decir sus últimas palabras? Acusado: Sí, quiero que siempre, absolutamente siempre, me recuerden como ese VOLVO V40 con mantenimiento durante 4 años por 21.307 euros.

Juez: Silencio en la sala.

LOC. OFF: Cuando aprovechas una oportunidad así necesitas contarla. Llévate uno antes de final de año financiándolo con Banco CETELEM. Condiciones con volvocars.es

(4) VOLVO. Título: «Boda» (noviembre 2016)

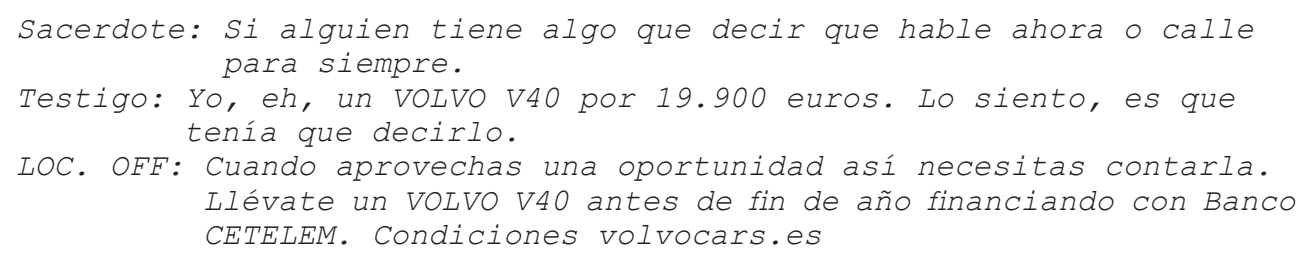

(5) Campofrío. Título: «Una buena base lo es todo» (julio 2016)

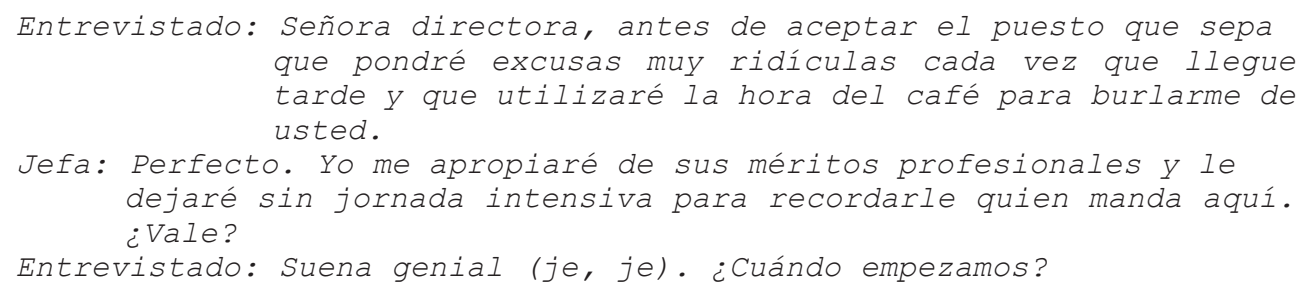

LOC. OFF: Una buena base lo es todo. Por eso la nuevas pizzas Finissimas de Campofrío tienen una base más fina y crujiente que las hace irresistibles. Pizzas Finissimas de Campofrío. Pruébalas.

En todos estos ejemplos, (3-5), las situaciones cotidianas son evocadas siempre por las palabras del primer interlocutor, que permite activar diferentes guiones: el veredicto de una sentencia judicial-«culpable»- remite a un juicio en (3); el acto

4 Real Academia Española (2001). Libro. En Diccionario de la lengua española (22a ed.). Consultado en http:// dle.rae.es/?id=NG3ktc6 (30/12/2016). 
de habla que pronuncia el sacerdote $-«$ Si alguien tiene algo que decir que hable ahora o calle para siempre»-, a una ceremonia nupcial en (4); las palabras de un aspirante a un puesto de trabajo - «Señora directora, antes de aceptar el puesto que sepa que ... »-, a una entrevista en (5). Y es, o bien en esa misma intervención iniciativa o bien en la de respuesta, donde se rompen las expectativas generadas por ese tipo de situaciones en las que se evocan diferentes guiones. En (3) resulta inesperada y lúdica la situación que se consigue mediante la personalización del producto que se anuncia, que responde como si fuera el acusado al veredicto emitido por el juez: «Sí, quiero que siempre, absolutamente siempre, me recuerden como ese VOLVO V40 con mantenimiento durante 4 años por 21.307 euros». En (4), el testimonio de un testigo del que se espera que argumente algún impedimento de peso para que no se produzca el enlace y, sin embargo, habla de un anhelo: el coche de sus sueños - «Yo, eh, un VOLVO V40 por 19.900 euros. Lo siento, es que tenía que decirlo»-. En (5), las palabras de un aspirante al puesto de trabajo - «pondré excusas muy ridículas cada vez que llegue tarde y que utilizaré la hora del café para burlarme de usted»-, así como la respuesta de su jefa -«perfecto. Yo me apropiaré de sus méritos profesionales y le dejaré sin jornada intensiva para recordarle quién manda aquí»-, resultan totalmente incongruentes y disparatadas, puesto que no corresponden a las opiniones que se espera que manifiesten quienes desempeñan esos roles (jefe-empleado), menos durante una entrevista de trabajo. Como señalan Pano Alamán y Mancera Rueda (2014: 512) -a partir del concepto de frame o marco de Goffman- salen de «ese lugar desde el que actuamos y del que no debemos salir si queremos causar buena impresión en aquellos con quienes interactuamos». Hay que destacar el juego constante sobre identidades, roles $^{5}$ sociales para generar humor en la publicidad.

Se parodia ese tipo de situaciones al hacer explícitos argumentos que corresponden a pensamientos que nunca se llegan a manifestar de forma explícita. La parodia suele implicar contraste y exageración de actitudes (Gallud Jardiel, 2016: 147). Coexisten dos textos que se retroalimentan: el de referencia y el paródico, que encuentra su fundamento en la burla del primero. Por ello, puesto que se intenta hacer recordar al oyente un acto previo y se pretende que lo reconozca (Ruiz Gurillo, 2012: 89), lo que nos interesa destacar es que, en este caso, se parodian situaciones perfectamente identificables por el oyente en tanto que interacciones cotidianas.

Dentro de la modalidad ficcional dramatizada, englobamos también aquellas cuñas en las que solo se reproduce una de las intervenciones de un posible diálogo como en (6), que es la respuesta de un niño, o el monólogo de un personaje (7). Este tipo de cuñas representan el $24 \%$ del total del corpus:

(6) El Corte Inglés. Título: «Lo saben» (noviembre 2016)

Niño: A mí siempre me ha encantado el puré de espinacas, un alimento

5 «Valores comúnmente asociados a ciertas posiciones sociales [...] que están socialmente sancionados y que abarcan distintos niveles, como el de las características sociales más o menos permanentes (género, edad), la situación en la que se encuentra la persona (visita, entrevista) y la que concierne a su participación en el discurso» (Pano Alamán y Mancera Rueda, 2014: 511). 
rico en fitonutrientes, vitamina A y minerales, como el calcio y

el fósforo, entre otros.

LOC.OFF: No sé cómo, pero lo saben. Ya está aquí el catálogo de juguetes de El Corte Inglés. Ahora con un 25 de regalo hasta el 23 de noviembre. Recógelo ya en El Corte Inglés.

(7) Pavofrío. Título: «Restaurante, deliciosa calma» (julio 2016)

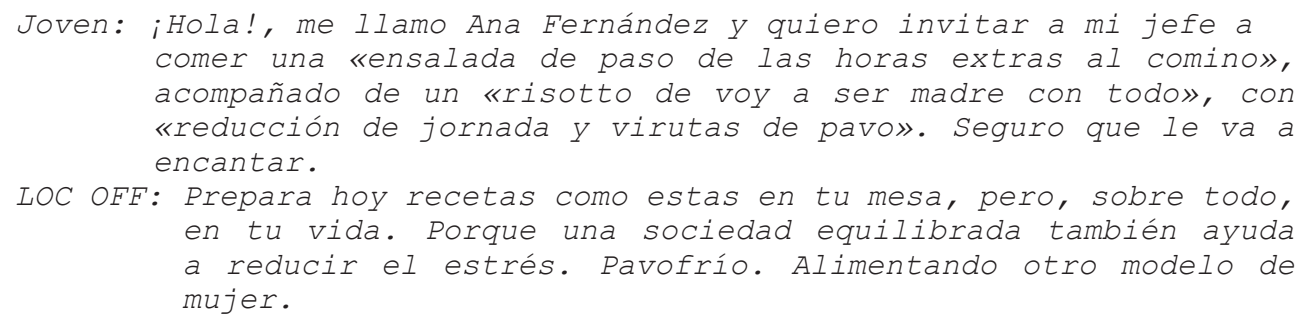

En (6) se alteran las expectativas del oyente no solo porque el niño manifieste lo contrario de lo que piensa, sino porque sus palabras resultan grandilocuentes y poco acordes con su edad. Lo cómico surge del procedimiento retórico del contraste entre el lenguaje esperable en un niño de su edad y el que manifiesta el protagonista, más propio de un adulto. La exageración en las palabras del niño y la enumeración y selección de términos técnicos - «alimento rico en fitonutrientes, vitaminas A y minerales como el calcio y el fósforo»-, que no son propios del sociolecto infantil ${ }^{6}$, constituyen indicadores de la ironía en la que se basa el efecto humorístico ${ }^{8}$.

En (7), resultan totalmente disparatadas las palabras de la protagonista, que se refiere realmente a lo que le diría a su jefe -paso de las horas extras, voy a ser madre, quiero reducción de jornada- Se presenta una oposición de dos guiones: aquel que evoca el menú de una carta y aquel otro correspondiente a la situación laboral en la que el empleado hace explícitas sus quejas al jefe.

Como puede comprobarse a partir de los ejemplos revisados, se recrean, como anticipábamos, situaciones perfectamente verosímiles, en principio, pero que se vuelven incongruentes en algún momento al romperse las expectativas generadas, lo que puede desencadenar entonces el efecto humorístico.

b) Ficción narrada y testimonial

La cuña se puede presentar también bajo la modalidad ficcional narrada $-29 \%$ de las

6 El grupo GRIALE, que se apoya en la pragmática neogriceana para explicar la ironía, asume que supone la inversión de los principios conversacionales. Si supone la inversión del requisito de Cualidad, también puede afectar al principio de Manera de Levinson (2000), y la variación (cambio de registro) puede activar las inferencias (Rodríguez Rosique, 2009, Ruiz Gurillo, 2012: 116,).

7 Ironía que se aprecia en todas las cuñas de la campaña: «Son las 7 de la mañana y tengo muchísimas ganas de ir al colegio para expandir mis experiencias y construirme como persona». «Todos los días me voy a dormir a las 9 de la noche porque es importante dormir lo suficiente para rendir bien durante el día».

8 Ironía y humor no son un mismo fenómeno. Véanse al respecto Ruiz Gurillo y Alvarado Ortega (2013: 5); Rodríguez Rosique (2013: 27-32) o Ruiz Gurillo (2012: 131-141). 
cuñas- o la de testimonial (4\%) (Arcos Foix y Perona, 2011: 6), modalidades a través de las que, o bien un narrador (8) o un personaje (9), cuentan una historia al oyente que puede resultarle cotidiana, pero que aderezan siempre con un toque humorístico:

(8) Aquarius. Título: «Vivos vivientes» (julio 2016)

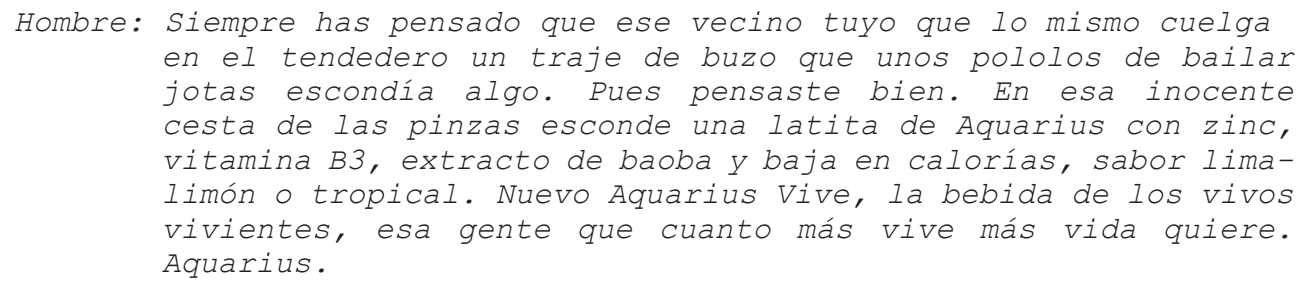

(9) Fanta. Título: «Balada» (julio 2016)

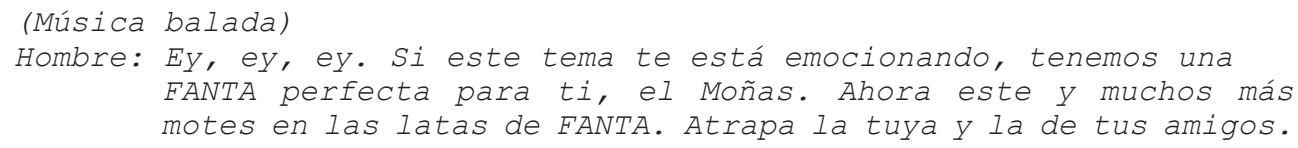

En (8), un narrador cuenta la historia con un tono lúdico y distendido, la misma elocuencia que podría manifestar un amigo, familiar o alguien próximo en una situación cotidiana. La fuente del humor reside en los elementos inesperados a los que hace referencia para caracterizar a un personaje excéntrico de forma elocuente y chistosa: «lo mismo cuelga en el tendedero tanto un traje de buzo que unos pololos para bailar jotas». Y, lo más cómico, por disparatado y absurdo, es que esconde una latita - no es gratuito el diminutivo - de refrescos en la cesta de las pinzas de la ropa. El razonamiento que permite resolver la incongruencia se basa en la exageración. Pero la intertextualidad por la remisión al cuento de Caperucita roja también contribuye a potenciar el efecto cómico.

En (9), el humor se desencadena a partir del mote lúdico «El Moñas» pues está basado en la forma coloquial metafórica empleada para aludir a una borrachera (moña). Pero resulta más cómico aún que este aparezca en las latas personalizadas de un refresco, algo que rompe las expectativas del potencial consumidor sobre esa bebida, pero que responde al afán publicitario por prolongar la cotidianeidad del oyente.

Como en los ejemplos de ficción dramatizada, dialógica o no, es habitual que las palabras del narrador, o el testimonio de un personaje - mayoritariamente anónimoal que se cede la palabra, recreen esas situaciones lúdicas muy cotidianas en las que son frecuentes la broma, el chiste o la frase elocuente para generar empatía con el interlocutor. De hecho, este tipo de cuñas se suelen presentar también utilizando otras estrategias narrativas: un chiste o un acertijo.

(10) Citroën. Título: «Cámara trasera» (julio 2016)

Joven: Se abre el telón y aparece un Citroën Jumpi con ojos en la nuca. ¿Cómo se llama la película? Nada es imposible. 
LOC. OFF: Nuevo Citroën Jumpi con cámara de visión trasera. Para que no haya ninguna sorpresa.

\subsubsection{Humor e intertextualidad}

Dado que, como hemos anticipado en el epígrafe 4.1., el humor requiere al oyente un mayor esfuerzo de procesamiento cognitivo; la publicidad, en general, recurre a la intertextualidad, que depende del «conocimiento que tengan los participantes en la interacción comunicativa de otros textos anteriores relacionados con él» (Beaugrande y Dressler, 1997: 247), algo que sucede en el 40\% de las cuñas del corpus, lo que da cuenta del interés de esta estrategia.

Puesto que el humor intertextual presupone que la audiencia comparta el conocimiento de un discurso precedente (Blanco Rodríguez, 2006: 75), en la publicidad en general y, en la modalidad radiofónica en particular, dadas las características del medio, puede resultar más dificultoso para los oyentes identificar el texto previo que permita entender la cuña. Pensemos que, en la radio, los mensajes se suceden vertiginosamente y que no existe posibilidad de volver a escucharlos, además de que la escucha se simultanea habitualmente con la realización de otras actividades. Por ello, la cuña debe remitir a textos y discursos fácilmente identificables por el oyente, que no le supongan un esfuerzo de procesamiento cognitivo tal que dificulte el proceso inferencial que debe realizar para llegar a la adecuada comprensión del mensaje.

El cine, la literatura (la poesía, el teatro, la narrativa) (Escribano, 2011), la propia publicidad de otros medios -fundamentalmente la televisión- o de otras épocas, el discurso político, jurídico o el cómic, se convierten en las fuentes de las que bebe la publicidad, que aprehende de esos otros discursos, frases célebres, personajes y todo tipo de recursos para llamar y captar la atención del oyente. Sin embargo, no siempre que se recurre a la intertextualidad se producen efectos humorísticos. «El empleo de frases ya consagradas en un contexto nuevo puede resultar divertido si se produce un cambio de nivel o si los contextos son lo suficientemente antitéticos» (Gallud Jardiel, 2016: 123). De ahí que no solo se evoquen otros textos, sino que se distorsionen, exageren, o parodien al servicio del humor. Y para ello resultan claves la música o los efectos sonoros, pero, sobre todo, los rasgos paralingüísticos, que actúan como marcas humorísticas: las voces hiperarticuladas de los personajes de la ficción, con particularidades que contribuyen a imprimir carácter humorístico a la cuña (véase apartado 4.2.).

(11) Huffington post. Título: «NODO» (octubre 2016)

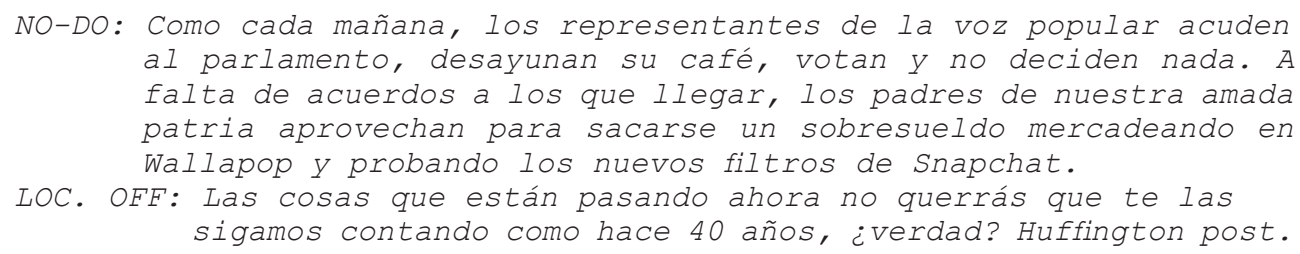


(12) Coca-Cola. Título: «Telenovela» (octubre 2016)

Mujer (VOZ HIPERARTICULADA): Mi Raúl Redondo, no podemos seguir juntos. Hombre: Pero Patricia Cuadrado, yo te amo.

Mujer: No lo entiendes. Unir nuestros apellidos haría sufrir a nuestros hijos. Cuadrado Redondo.

LOC. OFF: Hay apellidos muy distintos, pero ahora puedes encontrarlos todos en las latas de Coca-Cola. Personaliza tu etiqueta con tu nombre o apeliidos encompartecocacola.com.

En (11), se utiliza la sintonía y se imita la voz de un locutor del NO-DO noticiario que se emitía en los cines españoles antes de la película entre 1942 y 1981- para hacerse eco de una noticia actual de forma irónica como, de hecho, se pone de manifiesto en la voz en off. Las palabras ampulosas, arcaicas, marcadas ideológicamente con fines propagandísticos («los representantes de la voz popular», «los padres de nuestra amada patria»), no solo resultan humorísticas por su carácter anacrónico, sino porque son empleadas para caracterizar a políticos actuales cuyas actitudes, lejos de reflejar y exaltar comportamientos ejemplarizantes, resultan reprobables - «acuden al parlamento, desayunan su café, votan y no dicen nada», «mercadeando en Wallapop» (página online de compraventa) y «probando los nuevos filtros de Snapchat»-. El anuncio hace referencia de forma irónica, convirtiéndose incluso en una sátira burlesca, a la situación política actual, pues se recriminan las actitudes de los parlamentarios.

Los recursos no lingüísticos (la sintonía musical) y la voz que imita a un locutor del NO-DO adquieren un papel importante, pero el efecto humorístico surge no solo porque la voz del locutor resuene anacrónica, así como la música identificativa, sino por lo disparatado que resulta contar una noticia actual bajo ese formato -como, de hecho, se indica en la voz en off-. Y esos recursos sonoros que nos remiten a otra época también constituyen un gancho para que el oyente active un guion que resultará incongruente con aquel al que remite el contenido de la noticia, enmarcado en un contexto político actual.

En (12) se recurre al género de la telenovela, que se parodia con propósitos humorísticos. El humor se desencadena a partir del juego lingüístico que supone la creación de los dos apellidos de un personaje aludiendo a figuras geométricas. Si estos apellidos son comunes en español (Redondo y Cuadrado), la concurrencia de ambos resulta cómica. No solo se imita una telenovela, sino que se parodia el género, exagerando las actitudes de los personajes: la imposibilidad de una historia de amor entre dos personas con esos apellidos, algo que podría ser un lastre para sus descendientes; un hecho, sin duda, trivial. En esta ocasión, las voces hiperarticuladas -que no se perciben como naturales, sino afectadas-de los personajes de ficción actúan como marcas de humor, pero incluso habrían sido suficientes para desencadenar el efecto humorístico en tanto que imitación exagerada de una manera de hablar.

Como una forma de intertextualidad incluimos también en este apartado la retroalimentación de la publicidad radiofónica de campañas publicitarias previas difundidas en otros soportes. Si, como hemos señalado, la publicidad aprehende de forma recurrente recursos de otros discursos (literatura, cine), también la retroalimentación de campañas publicitarias se convierte en una estrategia particularmente eficaz. Especialmente, la publicidad televisiva -con más impacto 
que la radiofónica-, previa o simultánea a la emisión de la cuña, facilita al oyente de radio la evocación de imágenes que quizá resulten claves para conseguir la eficacia y efectividad del recurso humorístico en una campaña.

Por ejemplo, la campaña televisiva correspondiente a la cuña del ejemplo (1) (véase apartado 4.1.1.) resulta más elocuente, puesto que el personaje de la ficción publicitaria está reiterando su duda mediante «no sé», pero las imágenes visuales, que representan sus anhelos en forma de pensamientos que no manifiesta, contradicen sus palabras dubitativas. Las imágenes, rayanas a lo grotesco, muestran al personaje en situaciones irrisorias: en una fontana convertida en jacuzzi tomando café, cual si fuera la parodia de un excéntrico millonario; posando junto a una estatua dorada de su imagen en un alarde de narcisismo; como patrón de un barco, en una isla desierta; en un descapotable, tomando café en un helicóptero que parece haberlo recogido en la terraza de un bar. En el contexto del anuncio, las imágenes permiten interpretar la ironía de las palabras del personaje pero, aún más, resultan humorísticas en sí mismas por disparatadas, ya que permiten parodiar determinadas situaciones. Desde luego, resultan más cómicas que las palabras o los efectos sonoros de la cuña y, si el oyente las ha visto previamente, aunque coarten y restrinjan la capacidad que tiene la radio para involucrarlo en la creación de imágenes, también pueden ayudarlo a percibir la cuña correspondiente como humorística.

\subsection{Indicadores y marcas del humor: la palabra, la música, el paralenguaje y otros efectos sonoros}

Como hemos podido comprobar, a partir de los ejemplos analizados en los apartados 4.1.1. y 4.1.2., el efecto humorístico, que se articula en torno a la palabra en la publicidad radiofónica, se desencadena a partir de determinados mecanismos lingüísticos que actúan como indicadores de humor: ironía $(1,6)$, hipérbole o exageración $(2,8)$, enumeración o acumulación (1), ambigüedad (2), parodia (4, $5,7)$, personificación (3), metáfora (9). Además de otros recursos registrados en el corpus como repeticiones (13), fraseología (13), paronomasias (14) y antítesis (15).

(13) Ulabox. Título: «Instrucciones de un robot» (septiembre 2016)

Hombre: Entra a por el pimiento. Avanza por el pasillo del pimiento, encuentra el pimiento, coge el pimiento, haz cola con el pimiento, paga el pimiento, paga. La bolsa del pimiento, carga el pimiento. Y un pimiento.

(14) Línea Directa (diciembre 2016)

Chica: Mirándolo pensé iqué bueno!, es un Scooter. Y eso nadie, nadie lo discuter.

(15) Seguros Abanca. Título: «Plácido y Serena» (mayo 2016)

Mujer: Plácido y Serena son la tranquilidad en persona. 
Pero, aunque el efecto humorístico se articule en torno a la palabra, otros recursos resultan de extraordinaria eficacia y han de suplir la ausencia de imágenes visuales. Un papel preponderante desempeñan los rasgos paralingüísticos como los tipos de voces o las risas. Las voces hiperarticuladas, afectadas con características particulares - volumen, tempo, tono, timbre - que en nada se parecen a las voces propias de la locución radiofónica contribuyen a desencadenar el efecto humorístico, puesto que suelen exagerar las actitudes de los personajes parodiándolos (12). También, como en (5), las risas de los protagonistas mientras exponen sus argumentos actúan como marcas de humor ${ }^{9}$. Es más, sus voces desenfadadas en ese diálogo refuerzan los argumentos disparatados que ofrecen y su falta de seriedad ayuda a interpretarlos como incongruentes con las expectativas generadas por ese tipo de situaciones.

Por otra parte, la música de western puede, como en (16), permitir recrear un ambiente, aquel al que remite el guion que se activa al intentar describir de forma exagerada y elocuente la resistencia de un trabajador autónomo. Es decir, facilita la activación del guion que resulta incongruente con la descripción de un trabajador que el oyente podría esperar.

(16) Bankia. Título: «Inmortales» (mayo 2016)

(Música de western)

Hombre: Un autónomo puede cruzar el desierto sin agua y comiendo palomitas, que dan mucha sed. Los autónomos no parecen humanos, pero los gastos imprevistos también les duelen. Por eso, este trimestre financiamos con 2.000 millones a nuestros autónomos.

Del mismo modo, en (17), el efecto sonoro de los truenos contribuye a desencadenar el efecto humorístico al servir de apoyo a la traducción de Black Friday como 'viernes negro' y, por extensión, caótico y oscuro, al activar algunas connotaciones negativas del término negro.

(17) FIAT. Título: «Colour days» (noviembre 2016)

Hombre: Aunque todo en inglés suena mejor, el Black Friday no deja de ser un viernes negro, oscuro, caótico (truenos). Por eso fIAT te trae los Colour Days.

\section{Conclusiones}

La publicidad de radio parece haber encontrado en la ficción humorística un exponente de su creatividad. Prueba de ello es que constituye una apuesta decidida no solo en las campañas de ámbito local y regional -a cuyos intereses sirve en gran medida la radio-sino, sobre todo, en las de carácter nacional, como hemos podido constatar en

9 Ruiz Gurillo (2012: 79-80) distingue las marcas, que ayudan a interpretar el humor (pausas, intensidad de la voz, risas), de los indicadores de humor, que son elementos de por sí humorísticos que permiten generar incongruencia 
nuestro corpus de análisis obtenido a lo largo del año 2016, en el que la mayoría de los ejemplos corresponde a las grandes marcas (de telefonía, automoción, bebidas, alimentación, servicios, grandes superficies comerciales, seguros, sorteos, bancos e idiomas). El humor, dadas las posibilidades que ofrece para generar empatía, la adhesión emocional del consumidor, se convierte en una importante estrategia al servicio de la persuasión emocional. Ello no significa que el empleo del humor en publicidad sea algo novedoso, pero las manifestaciones empleadas para desencadenar el efecto humorístico sí han experimentado una evolución.

La cuñas de radio, que se pueden presentar bajo diferentes fórmulas de ficción dramatizada, narrada o testimonial-recurren en mayor medida a la dramatización de situaciones cotidianas, a la reproducción del prototipo discursivo de lo oral coloquial (la conversación entre amigos, familiares), así como de otro tipo de interacciones dialógicas (entre vendedor-cliente, jefe-empleado, juez-acusado, profesor-alumno). Es decir, se reproducen situaciones cotidianas fácilmente identificables por el oyente $\mathrm{y}$ en las que, de hecho, se encuentra inmerso de forma habitual, lo que parece estar en sintonía con las características de la radio como medio próximo que prolonga la cotidianeidad del oyente. Pero estas situaciones se distorsionan para desencadenar el efecto humorístico. El mayor esfuerzo de procesamiento cognitivo que supone interpretar el texto y los condicionantes de la publicidad radiofónica que, a pesar de contar con la música, el paralenguaje y otros efectos sonoros, no dispone del inestimable apoyo de las imágenes visuales, parecen determinar la recurrencia a esta estrategia. Del mismo modo, aunque en menor medida, el narrador o el testimonio de un personaje recrean situaciones lúdicas cotidianas en las que están presentes el chiste, la frase elocuente o la broma. Y, por las mismas razones, la intertextualidad (con el cine, la literatura) ha de remitir a textos cuyo referente sea fácilmente identificable por el oyente.

El análisis de los ejemplos a partir de la Teoría General del Humor Verbal nos ha permitido constatar que son diversos los mecanismos recurrentes para conectar los guiones (incongruentes) que se activan para desencadenar el efecto humorístico -tanto mecanismos lógicos basados en razonamientos como en relaciones sintagmáticas-También son diversas las estrategias narrativas empleadas -el diálogo en mayor medida, pero también la narración de una historia o anécdota por parte de un personaje que ofrece su testimonio o un narrador que se hace eco de ella, el chiste o la adivinanza-y los indicadores del humor (ambigüedad, personificación, hipérboles, repeticiones, metáforas, ironías, parodias, paronomasia). Pero que, de igual modo, el paralenguaje, la música y otros efectos sonoros permiten apoyar las palabras para activar el guion que resulte incongruente para desencadenar el efecto humorístico.

\section{Bibliografía}

Alvarado Ortega, Ma . B. (2016). «Variability, adaptability and negotiability in conversational humor: A matter of gender». En L. Ruiz Gurillo (Ed.), Metapragmatics of Humor. Current research trends. Amsterdam: John Benjamins Publishing Company, pp. 193-214. 
Arcos Foix, N. y Perona Páez, J. J. (2011). «Modalidades, usos y presencia de la ficción como recurso creativo en la publicidad radiofónica». Anàlisi, 43, pp. 1-19.

Attardo, S. (2001). Humorous Text: A Semantic and Pragmatic Analysis. Berlin: Mouton de Gruyter.

Attardo, S. y Raskin, V. (1991). «Script theory revis(it)ed: Joke similarity and joke representation model». Humor, 4, 3-4, pp. 293-347.

Beaugrande, R. A. y Dressler, W. U. (1997). Introducción a la lingüística del texto. Barcelona: Ariel.

Blanco Rodríguez, Ma . J. (2006). «El humor en el discurso publicitario». Español Actual, 86, pp. 49-80.

Catalá Pérez, M. (2010). «El humor en los mensajes publicitarios». En S. Robles y Mª V. Romero (Eds.), Publicidad y lengua española: un estudio por sectores. SalamancaZamora: Comunicación Social, pp. 163-174.

- (2011). «Ironía, humor e inferencia: procesos cognitivos: tendencias creativas en la publicidad actual». Acciones e investigaciones sociales, 12, pp. 129-142.

Charaudeau, P. (2006). «Des categories pour l'humour». Revue questions de communication, 2, pp. 19-41.

Duncan, C. P. y Nelson, J. E. (1985). «Effects of humor in a radio advertising experiment», Journal of Advertising, 14, 2.

Escandell Vida, Ma . V. (1999). «Los enunciados interrogativos. Aspectos semánticos y pragmáticos». En I. Bosque y V. Demonte (Eds.), Gramática descriptiva de la lengua española, 3. Madrid: Espasa, pp. 3929-3991.

Escribano Hernández, A. (2011). Literatura y publicidad: el elemento persuasivo-comercial de lo literario. Salamanca-Zamora: Comunicación Social.

Gallud Jardiel, E. (2016). Teoría y mecanismos del humor. Madrid: Carpe Noctem.

García Vizcaíno, Ma . J. (2010). «Quien no corre, vueling: el cambio de código como estrategia de cortesía en publicidad». En F. Orletti y L. Mariottini (Eds.), (Des)cortesía en español. Espacios teóricos y metodológicos para su estudio. Roma-Estocolmo: Università degli Studi Roma Tre-EDICE, pp. 245-260.

García Vizcaíno, M‥ J. (2016). «'Dime cómo vendes y te diré quién eres’: actividades de imagen e identidad en la publicidad de Yoigo». Soprag, 4(2), pp. 183-213.

Grupo Val.Es.Co. (2014). «Las unidades del discurso oral». Estudios de Lingüistica del Español, 35, pp. 13-73.

Guarinos, V. (1999). Géneros ficcionales radiofónicos. Alcalá de Guadaira: Mad.

Hernández Flores, N. (2010). «Actividades de imagen en la publicidad institucional española». En F. Orletti y L. Mariottini (Eds.), (Des)cortesía en español. Espacios teóricos y metodológicos para su estudio. Roma-Estocolmo: Università degli Studi Roma Tre-EDICE, pp. 261-264.

Hernández Toribio, Mª . I. (2006). El poder de la palabra en la publicidad de radio. Barcelona: Octaedro.

- y Vigara Tauste, A. Ma . (2011). «El humor como estrategia pragmática de cortesía y persuasión en la publicidad de radio». En D. Poch y S. Alcoba (Eds.), Cortesía y publicidad. Barcelona: Síntesis, pp. 203-219.

Kress, G. (2010). Multimodality: A social semiotic approach to contemporary communication. Londres: Routledge.

León, J. L. (2001). Mitoanálisis de la publicidad. Barcelona: Ariel.

López Díaz, M. (2008). «El humor como procedimiento discursivo en los anuncios publicitarios». Revue Romane, 43, 1, pp. 25-62. 
Muela Molina, C. (2012). «La representación de la ficción en la cuña publicitaria. Personajes, contextos y otros elementos narrativos». Área Abierta, 12, 1.

Muñoz, J. J. y Gil, C. (1994). La radio. Teoría y práctica. Madrid: Instituto Radio Televisión Española.

Pano Alamán, A. y Mancera Rueda, A. (2014): «Identidades falsas en Twitter: la ironía y el humor verbal como mecanismos paródicos». Discurso y Sociedad, 8, 3, pp. 507-536.

- (2016). «Humor and advertising in Twitter. An approach from the General Theory of Verbal Humor and Metapragmatics». En L. Ruiz Gurillo (Ed.), Metapragmatics of Humor. Current research trends. Amsterdam: John Benjamins Publishing Company, pp. 35-56.

Real Academia Española (2001). Diccionario de la lengua española. (22 ${ }^{\mathrm{a}}$ ed.). Consultado en http://www.rae.es/rae.html (Fecha de acceso: 16/12/2016).

Rodero Antón, E. y Soengas Pérez, X. (2010). Ficción radiofónica. Madrid: Instituto Radio Televisión Española.

Rodero Antón, E. (2014). «Posición serial y recursos atencionales para mejorar el recuerdo en las cuñas de radio». Revista Latina de Comunicación Social, 69, pp. 1-11.

Rodríguez Rosique, S. (2009). «Una propuesta neogriceana». En L. Ruiz Gurillo y X. A. Padilla (Eds.), Dime cómo ironizas y te diré quién eres: una aproximación pragmática a la ironía. Frankfurt: Peter Lang, pp. 109-133.

- y Provencio Garrigós, H. (2012). «Gigantes contra molinos: una explicación pragmática de la ironía y el humor en la publicidad». Revista de Investigación Lingüística, 15, pp. 251-267.

- (2013). «The power of inversión: irony, utterance to discourse». En L. Ruiz Gurillo y Mª B. Alvarado Ortega (Eds.), Irony and Humor: From pragmatics to discourse. Amsterdam: John Benjamins Publishing Company, pp. 17-38.

Ruiz Gurillo, L. (2012). La lingüistica del humor en español. Madrid: Arco/Libros.

- y M ${ }^{\mathrm{a}}$. B. Alvarado Ortega (Eds.) (2013). Irony and Humor: From Pragmatics to Discourse. Ámsterdam: John Benjamins.

- (2016). «Variability, negotiability and adaptability in humorous monologues». En L. Ruiz Gurillo (Ed.), Metapragmatics of Humor. Current research trends. Amsterdam: John Benjamins Publishing Company, pp. 79-101.

Torres Sánchez, Ma . A. (1999). Estudio pragmático del humor verbal. Cádiz: Universidad de Cádiz.

Verschueren, J. (2002). Para entender la pragmática. Madrid: Gredos.

Yus Ramos, F. (2016). Humor and Relevance. Amsterdam: John Benjamins Publishing Company. 